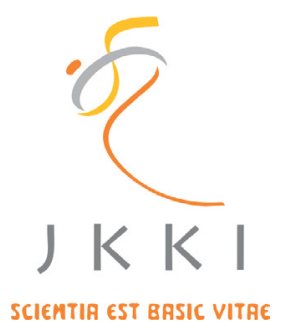

Jurnal Kedokteran dan Kesehatan Indonesia

Indonesian Journal of Medicine and Health

Journal homepage : www.journal.uii.ac.id/index.php/JKKI

\title{
Effectiveness of Asmaul Husna dhikr therapy to enhance the self con- trol of Alcohol Abuser
}

Ina Noor Khiyar Nafisa ${ }^{1}$, Fuad Nashori*1, Rumiani ${ }^{1}$

${ }^{1}$ Master of Professional Psychology, Faculty of Psychology and Socio-Cultural Sciences, Islamic University of Indonesia, Yogyakarta, Indonesia

Original Article

\begin{tabular}{|c|c|}
\hline & ABSTRACT \\
\hline ARTICLE INFO & $\begin{array}{l}\text { Background: Nowadays, alcohol abuse is increasing. It cause adverse } \\
\text { effects. Self-control is way to reduce such abuse. Asmaul husna dhikr }\end{array}$ \\
\hline $\begin{array}{l}\text { Keywords: } \\
\text { asmaul husna dhikr therapy, } \\
\text { self control, } \\
\text { alcohol abuser }\end{array}$ & $\begin{array}{l}\text { Objective: This research was conducted aiming to find out whether } \\
\text { Asmaul Husna dhikr could be used as treatment to enhance self-control } \\
\text { among alcohol abusers. } \\
\text { Methods: There were } 18 \text { alcohol abusers age between } 18 \text { to } 40 \text { years old }\end{array}$ \\
\hline $\begin{array}{l}\text { *Corresponding author: } \\
\text { fuadnashori@uii.ac.id }\end{array}$ & $\begin{array}{l}\text { as subject divided into two groups. The research used quasi-experimental } \\
\text { method with nonrandomized pretest-posttest-control group design, }\end{array}$ \\
\hline $\begin{array}{l}\text { DOI : } 10.20885 / J K K I . V o l 8 . I s s 3 . a r t 3 \\
\text { History: } \\
\text { Received: March 24, } 2017 \\
\text { Accepted: December 11, } 2017 \\
\text { Online: December 18, } 2017\end{array}$ & $\begin{array}{l}\text { comparing the conditions before and after treatment between two groups. } \\
\text { Self-control was measured by The Brief Self Control Scale (BSCS) adapted } \\
\text { from Tangney, Baumlister, and Boone }(2004) \text { scale, which self-discipline, } \\
\text { deliberate, healthy habits, work ethic and reliability as self-control aspects. } \\
\text { The experimental group participated in asmaul husna dhikr activities for } \\
\text { about } 2 \text { weeks. } \\
\text { Results: The result showed significant differences in self-control score } \\
\text { between experimental group and control group, by its significant level } \\
\text { showing p = } 0.001(\mathrm{p}<0.05) \text {. } \\
\text { Conclusion: Asmaul husna dhikr could be an effective treatment for } \\
\text { enhancing self-control among alcohol abusers. }\end{array}$ \\
\hline
\end{tabular}

Latar Belakang: Penyalahgunaan alkohol semakin meningkat saat ini dan dapat menyebabkan efek samping. Pengendalian diri adalah cara untuk mengurangi penyalahgunaan tersebut. Asmaul husna dhikr bisa digunakan sebagai self control yang efektif.

Tujuan Penelitian: Penelitian ini dilakukan untuk mengetahui apakah zikir Asmaul Husna dapat digunakan sebagai pengobatan untuk meningkatkan pengendalian diri di kalangan pecandu alkohol.

Metode: Terdapat 18 pengguna alkohol berusia antara 18 sampai 40 tahun dibagi menjadi dua kelompok. Metode yang digunakan dalam penelitian ini adalah kuasi eksperimental dengan rancangan kelompok pretest-posttest-control nonrandomized yaitu dengan membandingkan kondisi sebelum dan sesudah perlakuan antara dua kelompok. Pengendalian diri diukur dengan Skala Self Control Brief (BSCS) yang disesuaikan dengan skala Tangney, Baumister, dan Boone (2004), yang mengukur self-discipline, deliberate/ nonimpulsive, healthy habits, work ethic dan reliability sebagai aspek pengendalian diri. Kelompok eksperimen berpartisipasi dalam kegiatan zikir asmaul husna selama kurang lebih 2 minggu.

Hasil: Hasil penelitian menunjukkan perbedaan skor self control yang signifikan antara kelompok eksperimen dan kelompok kontrol, dengan tingkat signifikansi menunjukkan $p=0,001(p<0,05)$.

Kesimpulan: Zikir asmaul husna bisa menjadi pengobatan yang efektif untuk meningkatkan pengendalian diri pecandu alkohol. 


\section{INTRODUCTION}

Alcohol abuse and dependency in daily life had become a habit that was considered as a part of modern life today, even had become the trend of various social cultural backgrounds and religions. ${ }^{1,2}$ Actually, doing some activities interspersed with drinking alcoholic beverages were no longer prohibited, moreover in certain communities was a necessity. ${ }^{3,4,5}$ This course would provide its own influence for individuals in the social community. The influence itself would lead to the consequences of alcohol abuses by the emergence of addiction to alcohol. ${ }^{6}$

The World Health Organization (WHO) stated that deaths from alcohol abuse had reached 3,3 million peoples every year worldwide, with an average of every 10 seconds there were deaths from alcohol abuse. ${ }^{7}$ Research by the United Nations Office On Drugs And Crime (2013) also states the same thing that the prevalence of alcohol abuse is increasing every year, despite of a lot mass media campaigns about consuming alcohol would lead to addiction so did later risk of adverse health. ${ }^{8}$

Alcohol abuse and dependency adversely affected specifically for individuals who consuming it. ${ }^{9}$ More, Hawari (2011) stated that alcohol abusers would have changed in their behavior that affected physiologically, socially, and emotionally. ${ }^{10}$ Physiological changed such as impaired coordination body, cirrhosis, fetal syndrome, intoxication were leading to death, and so forth. Emotional changes can affect mood, difficulties in emotional control, and negative affective displayed. Social change was marked by violation to social norms in the society. Therefore, alcohol dependence would be referred to as a disease that requires specific therapy. ${ }^{11}$

American Psychiatric Association (2000), stated that alcohol abuse and dependency associated with certain mental disorders. It could be said that the problem itself requires special handling. The issue had become very important to be appointed as the fore problem related to the lives of individual in personal context, and individual in social context. Alcohol was a depressant of the central nervous system by inhibiting neuronal activity. ${ }^{12}$ This resulted in a loss of self-control and led to dangerous situation for individuals who consumed it as well as other people around them. ${ }^{13}$

Knowing the negative effect from alcohol dependence did not lead the abusers for discontinuing the habit. A common reason often cited by abusers of alcohol was because the alcohol helping to relieve anxiety, overcome moodiness, insomnia, and getting the pleasure. ${ }^{10}$ Alcohol abusers were in various range ages. ${ }^{13}$ A person who was becoming alcohol abusers said that alcohol was an escape way from their problem, in other words, 'drink' was considered as a 'problem solver.' ${ }^{14,15}$

Self-control was defined as ability within ourselves for composing, arranging, and directing ourselves to many forms of positive behaviors. ${ }^{16}$ Every individual had a different self-control mechanism. Among alcohol abusers, they tended to have lower self-control, and it led to maladaptive behaviors. ${ }^{17}$ Low self-control were shown by indicator in behavior such as could not control the urge of self that was destructive (angry, rebellious, and so on), easy to follow others to perform risk behavior (stealing, gambling, drunk in public places, etc) thus, tend to lead any anti-social behaviors. ${ }^{18}$

Based on the results of interviews to $\mathrm{MJ}$ (32 years old), he already consumed alcohol for approximately one year. This alcohol consumption was continuously done by MJ because he could not control his urge to drink alcohol whenever he was experiencing problems. MJ admitted it was hard for him not to drink alcohol despite of knowing every bad effects of alcohol itself. Tahaney, Kantner and Palfai (2014) observed that the lack of self-control made individuals less likely resistant to alcohol drinking habits. ${ }^{19}$

Other case of NZ (38 years old), he became alcoholics because of his environmental conditions that was common thing to get drunk in his environment. NZ could not withstand on the social pressure in his neighborhood forced NZ became an alcohol abusers. In NZ case, selfcontrol had its role to social control. Some studies 
suggested that people who were facing social situations that required in consuming alcohol and they had low self-control, they tend to follow its social situation to consume alcohol. Otherwise, if they had high self-control, they would not be affected by its pressing situation. ${ }^{13}$

Based on the description of two cases mentioned above, there was a relationship between self-control and alcohol abuse. In its theory and application, self-control might serve as a predictor of a person behavior in the future. ${ }^{20}$ In addition, if a person had high self-control, it would make them for having a good personality as well, and if they had low self-control, they would perform any psychopathological things inside themselves. ${ }^{21}$

Some treatments related to alcohol had been developed through the approach of religiosity. Religion approach could be used as a healing therapy. ${ }^{22,23,24}$ Dhikr therapy was one of kind therapies using religious approach and had shown its significant results in improving self-control. ${ }^{25,26,27,28}$ Dhikr in Islam was a way of worship that connecting directly to Allah (recollection of God), namely as a reminder that Allah was continuously in the hearts, minds, and behavior of people (As Sakandari, 1960). It was manifestation for any humankind to always remember God every day in everything they did, because of dhikrullah was a medicine to any disease inside us and was recited in the Qur'an Surah ar-Ra'du verses 28 which said: "Those who believe it firmly, stay calm his heart with the remembrance of Allah. Remember the remembrance of Allah hearts will be peaceful ". (Q.S. ar-Ra'du: (13) paragraph 28) “.

Dhikr therapy would be given as an intervention in this study by performing Asmaul Husna dhikr ( 99 beautiful names belong to Allah). Practicing all of 99 these names. Individuals who was practicing recollection of God in daily life, was expected to divert any their negative emotions into positive emotions. It was certainly a way for increasing the faith as a servant of God by always remembering Him. Through dhikr a person would also be able to experience changes in their cognitive function, mood, and self-control. ${ }^{29}$ The hypothesis of this study was: there was an increasing self-control in alcohol abusers who were given asmaul husna dhikr therapy as intervention compared to alcohol abusers who were not given its intervention.

\section{METHODS Subject}

Subjects of this research were low-middle level alcohol abusers based on the results of screening by The Alcohol Use Disorders Identification Test (AUDIT) of Boer, Hooft, and Bakker (2011), and had score low-middle level in self-control based on the results of self-control scale, had desires to recover from alcohol abuse, not under influences of alcohol when undergoing therapy based on the results of medical tests by doctors, aged 20-40 years (adulthood), Muslim, and lived in the province of Yogyakarta. All of subjects in this research are males and also did not a habbit of dhikr in their daily life. Because males have a less of self control well in terms of drinking alcoholic beverages. ${ }^{30}$

\section{Method of collecting data}

Methods for collecting data in this study were by observation, interviews, and using scale that contains some statements that would be answered by the participants. The self-control scale from translation of Brief Self-Control Scale (BSCS) of Tangney, was used to assign the participants. The self-control scale was using Likert-rating scale with 13 pieces of item statements and four alternatives answers for each statement. Item total correlation score for self-control scale was moving from 0.477 - 0.869 with its alpha coefficient was 0.914 .

\section{Research procedure}

First, preparation for module of asmaul husna dhikr therapy for alcohol abusers. Preparation of dhikr therapy module was developed by researcher referencing to the Al-Ghazali (undated) for the implementation of dhikr and its relation with psychological interventions. The researcher also conducted interviews with therapists who had the asmaul husna dhikr 
therapy techniques for drug abusers about how to implementing the therapy on those cases. Second, preparation for equipment and materials. Those were self-control scale, module of asmaul husna dhikr therapy, dhikr home dailyrecords worksheets, record sheet of the changing after conducting asmaul husna dhikr, and observation sheets. Third, implementation of the intervention (Asmaul husna dhikr therapy) only for the experimental group. The intervention is performed three meetings. As for the intervention as a whole include sessions namely, introduction, overview brief therapy remembering the asmaul husna, the formulation of the problem, giving the matery about self-control and alcohol abuse, the implementation of the dhikr of asmaul husna, assignments home, the implementation of the daily task of remembering the asmaul husna, share experience, and psychoeducation about remembering the asmaul husna. The Subjects required to listen asmaul husna in every morning and night for approximately one hour each session and conducted for two weeks. Fourth, implementation of the post are given by way of charging scale to the subject of self-control in the experimental group and the subjects in the control group and implementation of follow-up given to the experimental group and the control group to replenish self-control scale BSCS to determine the difference in self-control scores on the study subjects per group. AUDIT test and then given also to determine the category of the difference score levels of alcohol abuse.

\section{Data analysis techniques}

Data analysis techniques was using quantitative and qualitative data analysis. Quantitative analysis using non-parametric Mann Whitney Test. Qualitative data analysis was performed with individual interviews which aims to get direct expression of the subject during the intervention. Analysis of qualitative data is obtained through description from the observation and evaluation from the statement of each subject.

\section{RESULTS}

The above tables and graphics showed that during the implementation of the pre-test, post-test and follow-up, there was differences between the mean value of the experimental group and the control group. The experimental group showed increasing score during the posttest and follow-up significantly, while in the control group also showed increasing score but not significantly.

Results of Mann Whitney analysis that had been performed on pre-test data showed that the value of $Z=-1.35$ and $p=0.0893$ ( $p>0.05$ ). This showed that there was no significant difference between the experimental group and control group on pre-test. These results were considered due to the initial conditions of subjects in the two groups that was expected to equal or no difference. Then, the results of analyzes performed on the data after the test showed that the value of $\mathrm{Z}=-3.392$ and $\mathrm{p}=$ $0.001(p<0.01)$. This showed that there were significant differences in the implementation of the post-test between the experimental group and control group. The same condition also occurred in follow-up data, where the value of $\mathrm{Z}=-3.567$ and $\mathrm{p}=0.000(\mathrm{p}<0.01)$. This showed that there was significant difference between the experimental group and control group in of the follow-up conditions.

\section{DISCUSSION}

This study aimed to determine the effectiveness of asmaul husna dhikr therapy in increasing level of self-control among alcohol abusers. Based on data analysis that had been performed, the results indicated the changing of self-control level before the intervention and after the intervention given. The experimental group was given intervention by the asmaul husna dhikr therapy showing a significant change in the level of self-control before and after therapy given. While in the control group, the level of self-control did not perform any significant changes. According to the theory that the person who has a good of self control can control away from consumpting alcohol. ${ }^{3}$ 
Tabel 1. Description of Data

\begin{tabular}{lccccccc}
\hline \multirow{2}{*}{ Group } & Name & $\begin{array}{c}\text { Pre- } \\
\text { test }\end{array}$ & $\begin{array}{c}\text { Post- } \\
\text { test }\end{array}$ & $\begin{array}{c}\text { Follow- } \\
\text { up }\end{array}$ & $\begin{array}{c}\text { Gained } \\
\text { Score } \\
\text { (pre-post) }\end{array}$ & $\begin{array}{c}\text { Gained } \\
\text { score (post- } \\
\text { follow up) }\end{array}$ & $\begin{array}{c}\text { Gained } \\
\text { Score (pre- } \\
\text { follow up) }\end{array}$ \\
\hline Experiment & FR & 26 & 38 & 38 & 12 & 0 & 12 \\
& DD & 26 & 37 & 42 & 11 & 5 & 16 \\
& EA & 33 & 35 & 42 & 2 & 7 & 9 \\
& AM & 30 & 39 & 47 & 9 & 8 & 17 \\
& SU & 23 & 31 & 39 & 8 & 8 & 16 \\
& MJ & 25 & 34 & 42 & 9 & 8 & 17 \\
& TO & 21 & 43 & 45 & 22 & 2 & 24 \\
& TS & 25 & 41 & 44 & 16 & 3 & 19 \\
& NZ & 27 & 29 & 30 & 2 & 1 & 3 \\
& BR & 25 & 27 & 31 & 2 & 4 & 6 \\
& UL & 27 & 31 & 29 & 4 & -2 & 2 \\
& GF & 25 & 23 & 26 & -2 & 3 & 1 \\
& MM & 22 & 27 & 28 & 5 & 1 & 6 \\
& AA & 27 & 29 & 29 & 2 & 0 & 2 \\
& AI & 34 & 33 & 34 & -1 & 1 & 0 \\
& LS & 26 & 31 & 31 & 5 & 0 & 5 \\
& SO & 24 & 28 & 30 & 4 & 2 & 6 \\
& AS & 23 & 27 & 27 & 4 & 0 & 4 \\
\hline
\end{tabular}

Tabel 2. Description of Statistics

\begin{tabular}{lcccccccc}
\hline & \multicolumn{3}{c}{ Eksperiment Group } & \multicolumn{3}{c}{ Control Group } \\
& Min & Max & Mean & SD & Min & Max & Mean & SD \\
\hline Pre-test & 21 & 33 & 26,13 & 3,79 & 22 & 34 & 26,00 & 3,30 \\
Post-test & 31 & 43 & 37,25 & 3,88 & 23 & 33 & 28,50 & 2,79 \\
Follow Up & 38 & 47 & 42,38 & 2,97 & 26 & 34 & 29,50 & 2,27 \\
\hline
\end{tabular}

Tabel 3.Test Results Hypothesis

\begin{tabular}{lccl}
\hline Data & $\mathbf{Z}$ & $\mathbf{P}$ & Description \\
\hline Pre- test & $-1,35$ & 0,893 & Not Significant \\
Post- test & $-3,392$ & 0,001 & Significant \\
Follow Up & $-3,567$ & 0,000 & Significant \\
\hline
\end{tabular}




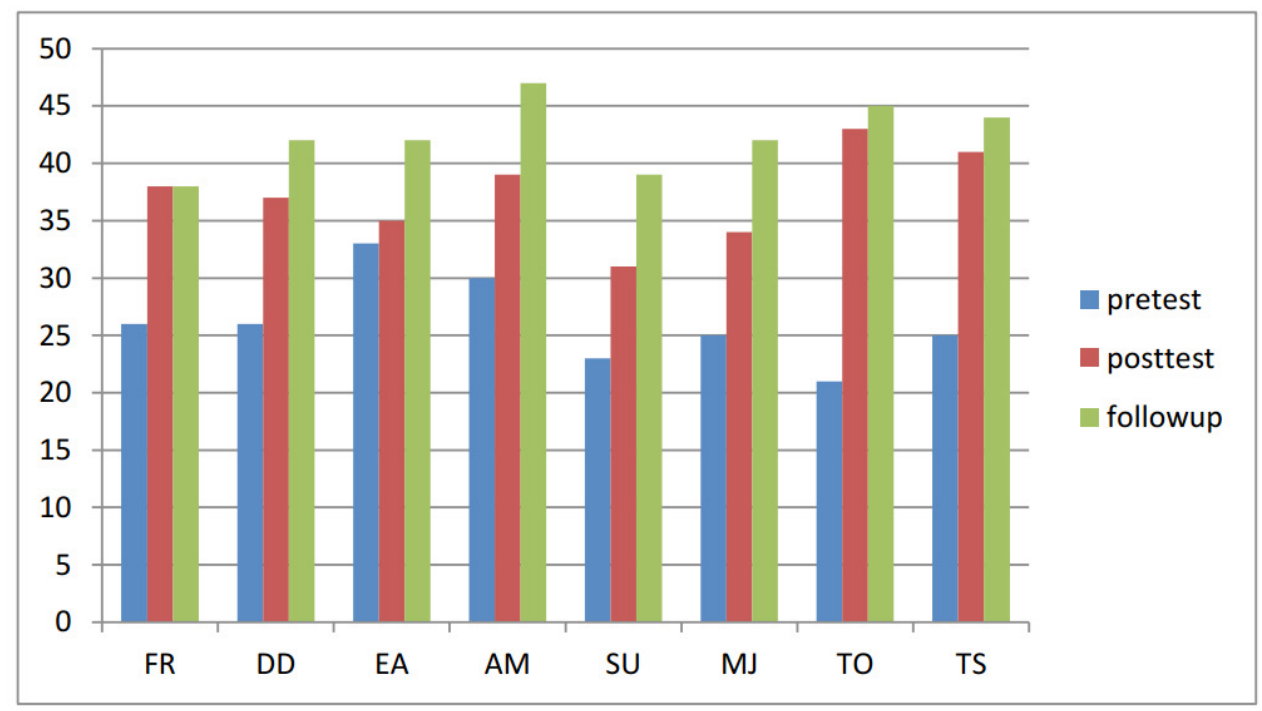

Figure 1. Graphics of changes in scores at pre-test, post-test, and follow-up experiment group

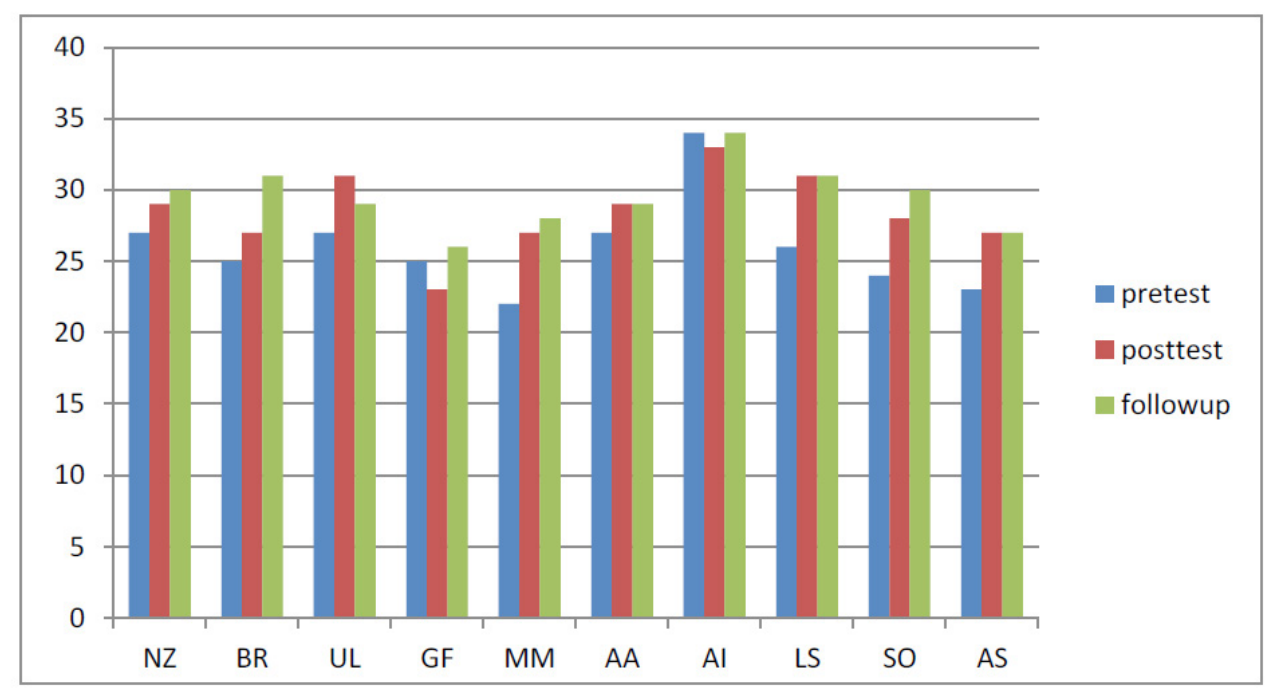

Figure 2. Graphics of changes in scores at pre-test, post-test, and follow-up control group

Quantitative analysis in this study could notice any changes between the pre-test and post-test was based on the difference between the average scores of self-control scores of each group. The average scores in the experimental group were 37.25 , while the average scores in the control group were 28.50. The Mann Whitney test was performed in both groups showing that the post-test scores 0,001 and the follow-up score was $0.000(\mathrm{p}<0.01)$, which meant that was no significant changes. This result supported the previous studies which stated that the asmaul husna dhikr therapy affected the improvement of self-control. ${ }^{31}$

Dhikr as therapy with Islam psychotherapy approaches, in the world of psychology, was included in the domain of meditation. As known, meditation had good effectiveness in improving people self-control. ${ }^{32,33,34}$ Self-control itself in 
Islam served as benchmarks of person in running order of Allah and avoided His prohibitions. ${ }^{35}$

Therapy dhikr of asmaul husna which was as an intervention in this study consisted of material about self-control, the relationship between self-control and alcohol abuse, as well as materials about the dhikr. The asmaul husna dhikr therapy designed in three meetings that include a pre-test, post-test, and follow-up. The interlude between the post-test and followup, researcher was conducting monitoring to the subject through homework sheet. The monitoring aimed to see the consistency of the subject in performing dhikr asmaul husna which had been given. Apart from that, it was also an attempt for making a habituation to the subject to perform dhikr, as dhikr was recommended to perform daily as a habituation. ${ }^{10}$

The changes that were experienced by subjects aside from quantitative analysis, it could also be seen from the qualitative analysis carried out by the researcher. It could be seen from the home assignment sheet and post-test sheet filled out by the subject during the process of study. Subject DD, TS, and JN said that the conditions experienced after doing dhikr therapy was they were getting sense of comfort and calm, and decreasing their anxiety, and fearing in their heart. This was consistent with what was specified by Allah in the meaning of Surah ArRa'du about dhikr could make the heart in state of calm. It supported the research conducted by Lukman (2012) and Nurfadilah, Firmawati, and Cahyati (2014) which stated that dhikr therapy could make the heart in the state of calm and reduce the level of discomfort, so was a person anxiety. ${ }^{36,37}$

Other subjects EA, TO, AM, and SU gained some positive changes, those were increasing vigor to work, more motivated, and began to accustom their selves to resist the temptation of friends or environment for consuming alcohol. This was consistent with what was expressed by the expert opinion that the social environment could be one of the for a person in consuming alcohol.38 Other research results mentioned that there was a tendency to say no to friends or coercion for consuming alcohol also caused by people who had low self-control. ${ }^{13}$

Application of the asmaul husna dhikr therapy as an intervention could be as a preventive method or as a curative method for low-medium level alcohol abusers. This was proven by the positive changes experienced by the subject of research, and also in accordance to the practical usefulness which had been described in the early chapters. The intervention for people who was categorized to addiction diagnosis for abusing alcohol, they would be needed more intensive treatment from the medical side. Pinel (2009) said in biopsychology study that when the individual had undergone addiction to alcohol, the medical treatment was above to any treatment which was a treatment to overcome alcohol intoxication in their body, meanwhile individuals in the category of alcohol abusers who did not have dependencies on alcohol, could be addressed through the application of psychological intervention. ${ }^{12}$

Lindgren et al (2014) had observed that the behavior of individuals who becoming alcohol abusers would have a negative effect, not only on the individuals themselves, but also to the people around them..$^{39}$ Therefore, Islam as a religion rahmatan lil alamin in psikosufistik teachings had explicitly described that individuals with good self-control would appear as a sense of security for the people around him. ${ }^{35}$ Individuals who could provide security for others, named as a believer (in Arabic: Aamin). Alcohol abusers tended to make people around them feeling uneasy and uncomfortable. Therefore, dhikr could be as a tool to change the social environment to be psychologically safe.

Adz-Dzakiey (2013) revealed that dhikr could become a tool for people to achieve the degree of piety, characterized by a process of reform (yuhsin nafsahu). ${ }^{40}$ Dhikr also could be a method of psychological intervention as many studies also used dhikr as a therapy method for intervention. ${ }^{41}$ Those research were conducted by Anggraieni and Subandi (2014) concerning the dhikr therapy to reduce stress, the research conducted by Mudzkiyyah, Nashori, 
and Sulistyarini (2014) on the effect of dhikr alfatihah therapy to enhance anxiety mong drugs abuser on rehabilitation. ${ }^{42,43}$ It also showed that the health aspects of physical, psychological, and spiritual having its main reference that was in the Qur'an. ${ }^{44}$

\section{CONCLUSION}

Based on the analysis of data and discussion that had been performed, it could be concluded that the asmaul husna dhikr therapy proved to be effective in improving self-control in alcohol abusers. The research indicated that the issues of self-control or dependance abuse (alcohol) can be solved using Islamic psychotherapy approach.

\section{RECOMMENDATION}

This research had been carried out by following the procedures that have been maximally designed and implemented. Based on the implementation and consideration, the researcher gave suggestions to the subject of research to keep applying asmaul husna dhikr in every day, and doing deeds as a Muslim, like the praying five times a day, so the repentance could be ongoing until the end of life, since prayer was also one of dhikrullah which were obligatory for every Muslim. The suggestion for further research was to be stricter in scheduling time for the subject to feel comfortable and not to feel rushed for carrying out other activities outside the therapy process.

\section{REFERENCES}

1. Foster DW, Young CM, Bryan JL, Quist MC. Compounding risk: An examination of associations between spirituality/religipsity, drinking motives, and alcohol-related ambivalence among heavy drinking young adults. Addictive Behaviors. 2016;63(1):111.

2. Halim A, Hasking P, Allen F. The role of social drinking motives in the relationship between social norms and alcohol consumption. Addictive Behaviors. 2012;37(12):1335-41.

3. Weafer J, Fillmore MT. Alcohol-related cues potentiate alcohol impairment of behavioral control in drinkers. Psychology of Addictive Behaviors. 2015;29(2):290-9.

4. Walter R, Fillmore MT. Attention bias to alcohol-related stimuli as an indicator of changes in motivation to drink. Psychology of Addictive Behaviors. 2015;29(1):63-70.

5. Foster DW, Neighbors C. Self-consciousness as a moderator of the effect of social drinking motives on alcohol use. Addictive Behaviors. 2013;38(4):1996-2002.

6. Quinn PD, Fromme K. Self-regulation as a protective factor against risky drinking and sexual behavior. Psychology of Addictive Behaviors. 2010;24(3):376-85.

7. www. okezone.com. Penyalahgunaan alkohol, anak muda rentan lakukan kriminalitas [Internet]. 2016 [cited 2017 Aug 11]. Available from: http://news.okezone.com/ $\mathrm{read} / / 2016 / 05 / 15 / 337 / 1388904 /$ penyalahgunaan-alkohol-anak-muda-rentan-lakukan-kriminalitas

8. United nations office on drugs and crime. World drug report. Vienna: Division for policy analysis and public affairs UNODC; 2013.

9. Bankole AJ. Medication treatment of different types of alcoholism. American Journal of Psychiatry. 2010;167(6):630-9.

10. Hawari D. Petunjuk praktis terapi (detoksifikasi) miras dan narkoba/NAZA (Narkotika, Alkohol dan Zat Adiktif) tanpa anestesi dan substitusi(Metadone, Subutex dan sejenisnya) dan HIV AIDS. Jakarta: Fakultas Kedokteran UI; 2011.

11. Ksir C, Hart CL, Ray O. Drugs, society and human behavior. 12th ed. Boston: McGraw-Hill; 2008.

12. Pinel JPJ. Biopsychology. 7th ed. Boston: Pearson Educatin, Inc; 2009.

13. Gerich J. The inhibiting function of self-control and social control on alcohol consumption. Journal of Drug Issues. 2014;44(2):120-31.

14. Purvis DM, Gallagher KE, Parrot DJ. Reducing alcohol-related aggression: Effects of a self-awareness manipulations and locus of control in heavy drinking males. Addictive Behaviors. 2016;58(1):31-4. 
15. Davis AK, Rosenberg H. Acceptance of non-abstinence goals by addiction professionals in the United States. Psychology of Addictive Behaviors. 2013;27(4):1102-9.

16. Lazarus RS. Patern of adjusment. 3rd ed. Tokyo: Mc Graw Hill Kogakusha, Ltd; 1976.

17. De Ridder DTD, Boer BJ, Lugtig P, Bakker $A B$, Hooft EAJ. Not doing bad things is not equivalent to doing the right thing: Distinguishing between inhibitory and initiatory self-control. Personality and Individual Differences. 2011;50(7):1006-11.

18. Reisig MD, Pratt TC. Low self-control and imprudent behavior revisited. Deviant Behavior. 2011;32(7):589-625.

19. Tahaney KD, Kantner CW, Palfai TP. Executive function and appetitive processes in the self-control of alcohol use: the moderational role of drinking restraint. Drug Alcohol Dependence. 2014;138:251-4.

20. De Ridder DTD, Lensvelt-Mulders G, Finkenauer C, Stok FM, Baumeister RF. Taking stock of self-control: A meta-analysis of how trait self-control relates to a wide range of behaviors. Personality and Social Psychology Review. 2012;16(1):76-99.

21. Tangney JP, Baumeister RF, Boone AL. High self control predicts good adjustment, less pathology, better grades, and interpersonal success. Journal of Personality. 2004;72(2):271-324.

22. Sabry WM, Vohra A. Role of Islam in the management of psychiatric disorder. Indian Journal of Psychiatry. 2013;55(6):20514.

23. Sholeh M, Musbikin I. Agama sebagai terapi telaah menuju ilmu kedokteran holistik. Yogyakarta: Pustaka Pelajar; 2005.

24. Mansyur. Pengaruh dzikir terhadap penanggulangan stress: suatu bentuk psikoterapi islami. Universitas Muslim Indonesia Makasar; 2008.

25. Istiqomah IN. Reduced addiction in drugs abusers undergoing dhikr at Ponpes Inabah XIX Surabaya. Journal of Folia Medica Indonesia. 2013;49(1):8-11.

26. Aisyah D, Norizan, Ibrahim, Manam A, Sontang M. Drug addict treatment and rehabilitation programme at Pondok Inabah, Kuala
Terengganu, Terengganu, Malaysia. British Journal of Social Science. 2013;1(5):37-46.

27. Pujiastuti T. Psikoterapi Islam sebagai metode dakwah: Studi psikoterapi Abah Anom terhadap pecandu narkoba. Jurnal Syi'ar. 2012;12(2).

28. Astutik S. Psikoterapi islami dalam mengatasi ketergantungan narkoba di Pondok Pesantren Inabah Surabaya. Surabaya: Universitas Islam Negeri Sunan Ampel; 2011.

29. Subandi MA. Psikologi zikir: studi fenomenologi pengalaman transformasi religious. Yogyakarta: Pustaka Pelajar; 2009.

30. Lyons A, Emslie C, Hunt K. Staying in the zone' but not passing the 'point of no return': embodiment, gender and drinking in mid-life. Sociolology of Health and Illness. 2014;36(2):264-77.

31. Maghfuron. Pengaruh intensitas dzikir al-asmaul husna terhadap kontrol diri pada jama'ah majelis dzikir di Masjid Agung Jawa Tengah. Semarang: Fakultas Dakwah IAIN Walisongo; 2008.

32. Afrinaldi, Amir R, Arif M. Psycho religious theraphy through prayers and dzikir in islamic psychology perpective. Scientific Journal of PPI-UKM. 2015;2(4).

33. Friese M, Messner C, Schaffner Y. Mindfulness meditation counteracts self-control depletion. Consciousnessand Cognition. 2012;21(2):1016-22.

34. Crescentini C, Urgesi C, Campanella F, Eleopra R, Fabbro F. Effects of an 8-week meditation program on the implicit and explicit attitudes toward religious/spiritual self-representations. Consciousness and Cognition. 2014;30:266-80.

35. Isa AQ. Haqa'iq at-tasawwuf. Khairul A, Harahap, Afrizal L, editors. Jakarta: Qisthi Press; 2006.

36. Lukman. Pengaruh intervensi dzikir ssmaul husna terhadap tingkat kecemasan klien sindrom koroner akut di RSUP Dr. Mohammad Hoesin Palembang. Bandung: Universitas Padjadjaran; 2012.

37. Nurfadillah E. Pengaruh membaca dzikir asmaul husna terhadap kecemasan pada pasien pre operasi di RSU PKU Muhammadiyah Bantul. [Yogyakarta]: Fakultas Ke- 
dokteran dan Ilmu Kesehatan, Universitas Muhammadiyah; 2014.

38. Baron RA, Byrne D. Psikologi sosial. Jakarta: Erlangga; 2003.

39. Lindgren KL, Neighbors C, Westgate E, Salemink. Self-control and implicit drinking identity as predictors of alcohol consumption, problems, and cravings. Journal of Studies on Alcohol and Drugs. 2014;7(2):290-8.

40. Adz-Dzakiey HB. Prophetic intelligence kecerdasan kenabian menumbuhkan potensi hakiki insan melalui pengembangan kesehatan ruhani. Yogyakarta: Al Manar; 2013.

41. Nashori F. Pengembangan intervensi psikologi dengan pendekatan psikologi Islam. In: The First Inter-Islamic University Conference on Psychology and The First National Conference on Islamic Psychology. Yogyakarta: Islamic University of Indonesia; 2015.

42. Anggraieni $W N$, Subandi. Pengaruh terapi dzikir untuk menurunkan stres pada penderita hipertensi esensial. Jurnal Intervensi Psikologi. 2014;6(1):81-102.

43. Mudzkiyyah L, Nashori HF, Sulistyarini I. Terapi zikir Al-Fatihah untuk meningkatkan kesejahteraan subjektif pecandu narkoba dalam masa rehabilitasi. Jurnal Intervensi Psikologi. 2014;6(2):23-44.

44. Hawari D. Al Quran ilmu kedokteran jiwa dan kesehatan jiwa (edisi ketiga). Yogyakarta: PT. Dana Bhakti Prima Yasa; 2004. 